\title{
Effects of phosphate deficiency on photosynthesis and accumulation of starch and soluble sugars in 1-year-old seedlings of maritime pine (Pinus pinaster Ait)
}

\author{
M Ben Brahim¹, D Loustau ${ }^{1}$, JP Gaudillère², E Saur ${ }^{1}$ \\ ${ }^{1}$ Laboratoire d'écophysiologie et de nutrition, Inra, domaine de l'Hermitage, \\ BP 45, 33611 Gazinet cedex; \\ 2 Station de physiologie végétale, centre de recherche de Bordeaux, Inra, \\ $B P$ 81, 33883 Villenave-d'Ornon, France
}

(Received 27 April 1994; accepted 14 November 1995)

\begin{abstract}
Summary - Maritime pine seedlings were grown in $4 \mathrm{~L}$ pots filled with coarse sand in a greenhouse. Seedlings were supplied with a nutrient solution with three different concentrations of phosphorus $(0$, 0.125 and $0.5 \mathrm{mM}$ ). After 1 year of growth, gas exchange measurements were performed on mature needles. From these measurements, the main parameters of $\mathrm{CO}_{2}$ assimilation (the carboxylation efficiency, the apparent quantum efficiency and the maximal rate of electron transport) were estimated using the biochemical model of photosynthesis as described by Farquhar et al (1980). Leaf nonstructural carbohydrates were also analyzed. Phosphorus deficiency decreased the phosphorus foliar concentration, but did not affect foliar nitrogen concentration. The maximal rate of photosynthesis, the carboxylation efficiency and the apparent quantum efficiency decreased in phosphorus deficient seedlings. However, the maximal rate of electron transport and stomatal conductance were not affected by phosphorus supply. Low phosphorus nutrition caused a dramatic increase in foliar starch level at the end of the photoperiod. These results indicate that inadequate phosphorus nutrition principally affected the dark reactions of photosynthesis, the apparent quantum efficiency and starch accumulation.
\end{abstract}

\section{Pinus pinaster / growth / photosynthesis / phosphorus deficiency / glucidic status}

Résumé - Effets d'une carence en phosphate sur la photosynthèse et l'accumulation d'amidon et de sucres solubles chez des plants de pin maritime (Pinus pinaster) âgés d'un an. Des plants de pin maritime ont été élevés en pot de $4 \mathrm{~L}$ sur sable grossier, et alimentés avec une solution nutritive coulante suivant trois concentrations différentes de phosphore $(0,0,125$, et $0,5 \mathrm{mM})$. Après une saison de croissance, des mesures d'échanges gazeux ont été réalisées sur les aiguilles matures. $\dot{A}$ partir de ces mesures, les principaux paramètres de l'assimilation de $\mathrm{CO}_{2}$ (l'efficience de carboxylation, l'efficience quantique, et le flux maximal de transport d'électrons) ont été estimés par échanges gazeux. Le statut glucidique foliaire a été aussi analysé. La carence phosphatée fait diminuer la teneur en phosphate des aiguilles sans modifier celle de l'azote. Le taux de photosynthèse maximale, l'efficience de carboxylation, ainsi que l'efficience quantique apparente diminuent chez les plants carencés en phosphate. Parallèlement le flux maximal de transport d'électrons et la conductance stomatique ne semblent pas être affectés parla nutrition phosphatée. La carence phosphatée augmente la teneur 
en amidon dans les aiguilles à la fin de la photopériode. Ces résultats montrent que la carence phosphatée affecte principalement les réactions sombres de la photosynthèse, l'efficience quantique apparente, et l'accumulation d'amidon.

Pinus pinaster / croissance / photosynthèse / carence phosphatée / statut glucidique

\section{INTRODUCTION}

Phosphorus availability in forest soils is an important limiting factor for tree growth and consequently, carbon immobilization. However, little is known about the effects of phosphorus deficiency on carbon assimilation in forest tree species (Ericsson and Ingestad, 1988). In Australia, P fertilization of Pinus radiata increased stand biomass and the maximal rate of photosynthesis (Sheriff et al, 1986). The same results were observed in Eucalyptus grandis seedlings (Kirschbaum et al, 1992). At the current partial pressure of $\mathrm{CO}_{2}$, phosphorus deficiency decreased total dry matter and the rate of photosynthesis and increased foliar starch level in $P$ radiata seedlings (Conroy et al, 1990). In contrast, the effects of phosphorus deficiency on photosynthesis in annual plants has a more extensive coverage. It is widely recognized that a reduction in nutrient availability affects the dark reactions of photosynthesis and decreases carboxylation efficiency (Brooks, 1986; Lauer et al, 1989). In addition, it has been reported that phosphorus deficiency also decreases the quantum efficiency (Jacob and Lawlor, 1991, 1993; Lewis et al, 1994), but has no effect on the maximal rate of electron transport (Lewis et al, 1994). Phosphorus deficiency has small effect on stomatal conductance (Kirschbaum and Tompkins, 1990; Jacob and Lawlor, 1991, 1993)

Maritime pine is an important, fast-growing forest species which is widely used in southwestern Europe (4 Mha). In the Landes de Gascogne Forest, maritime pine exhibits a dramatic response to phosphorus fertilization, and $P$ fertilization is widely used in plantation forests (Gelpe and Guinaudeau, 1974; Gelpe and Lefrou, 1986). Under greenhouse conditions, phosphorus supply increased the biomass of 1-year-old maritime pine seedlings (Saur, 1989). However, there have been no studies on the effects of $P$ deficiency on $\mathrm{CO}_{2}$ assimilation rate in this species. In this paper, we determined the effects of $P$ deficiency on the photosynthesis and nonstructural carlıohydrate content in maritime pine seedlings. The main parameters of the biochemical model of $\mathrm{CO}_{2}$ assimilation of Farquhar et al (1980) were calculated. The contribution of stomatal conductance and leaf nonstructural carbohydrate to the limitation of photosynthesis in P-deficient plants are discussed.

\section{MATERIALS AND METHODS}

\section{Plant material and growth conditions}

Seeds of maritime pine ( $P$ pinaster) (INRA-CEMAGREF) were germinated on natural peat for 1 month. After germination, 60 seedlings were moved into $4 \mathrm{~L}$ pots filled with coarse sand in an unheated greenhouse with a cooling system. Seedlings were supplied twice an hour with tap water using an automated intermittent flowing system for 18 weeks. In March 1993, seedlings were irrigated with a nutrient solution $(\mathrm{pH}=4.5)$. Three treatments ( 20 seedlings per treatment) were applied and these were: 0 (PO or $P$ deficient), 0.125 (P1) or 0.5 (P4) mM P. All nutrient solutions contained $2,0.5,0.25,0.25,0.25,0.1$ $\mathrm{mM}$ of $\mathrm{N}, \mathrm{K}, \mathrm{Ca}, \mathrm{Mg}, \mathrm{S}$, and $\mathrm{Fe}$, respectively, and $16,3,0.3,0.3,0.03,0.03 \mu \mathrm{M}$ of $\mathrm{B}, \mathrm{Mn}, \mathrm{Zn}, \mathrm{Cu}$, Co and Mo, respectively. In October 1993, after one growing season, three seedlings of each treatment were selected for needles gas exchange and leaf nonstructural carbohydrate measurements. 


\section{Measurement of gas exchanges}

Photosynthetic measurements were performed on fully expanded brachiblast needles of three seedlings from each treatment. The photosynthetic rate $(A)$ was measured in an open-gas exchange system with controlled environment (Minicuvette compact system, Walz, Germany) at $22{ }^{\circ} \mathrm{C}, 75 \%$ of relative humidity, and various levels of $\mathrm{CO}_{2}$, and under a range of light intensities. Specifically, light and $\mathrm{CO}_{2}$ curves were generated. The total leaf area of the needles was calculated assuming a semi-cylinder shape, length and diameter of each needle inserted in the cuvette being measured.

\section{$\mathrm{CO}_{2}$ response curves}

The photosynthetic rate response to leaf internal partial pressure of $\mathrm{CO}_{2}(G)$ was obtained by decreasing the ambient concentration of $\mathrm{CO}_{2}\left(c_{a}\right)$ from 150 to $0 \mathrm{~Pa}$. Oxygen levels and photosynthetically active radiation levels were maintained at $21 \mathrm{kPa}$ and $1500 \mu \mathrm{mol} \mathrm{m} \mathrm{m}^{-2} \mathrm{~s}^{-1}$, respectively. Photosynthesis was measured 20 min after each change in $c_{\mathrm{a}}$. The maximal rate of photosynthesis $\left(A_{\max }\right)$ was defined as the rate of photosynthesis at $c_{\mathrm{a}}=150 \mathrm{~Pa}$. The maximal rate of carboxylation $\left(V_{c \max }\right)$ was calculated according to Von Caemmerer and Farquhar (1981) and Harley et al (1992). Under light saturated conditions and $c$ below $20 \mathrm{~Pa}$, ribulose 1,5-bisphosphate (RubP) regeneration is assumed to be not limiting and $\mathrm{CO}_{2}$ assimilation is given by:

$$
A=\frac{V_{\text {cmax }}(C i-\Gamma *)}{C i+K_{\{1\}}(1+O / K o)}-R d
$$

where $\Gamma^{*}$ is the $\mathrm{CO}_{2}$ compensation point in the absence of light respiration, and $\mathrm{O}$ and $\mathrm{Ci}$ are the partial pressures of oxygen and $\mathrm{CO}_{2}$ inside the leaf, and $K C, K o$ are the Michaelis-Menten constants of Rubisco for $\mathrm{CO}_{2}$ and $\mathrm{O}_{2}$ and $R d$, the day (light) respiration, is defined as that $\mathrm{CO}_{2}$ evolved other than through the photorespiratory pathway. The $K c$ and $K o$ are dependent on leaf temperature and were calculated according to Leuning (1990) (36 Pa and $28.7 \mathrm{kPa}$, respectively, at $22^{\circ} \mathrm{C}$ giving a value of $\Gamma^{*}=2.5 \mathrm{~Pa}$ ). Nonlinear least squares regression was used to determine the values of $R d$, and $V_{c \text { max }}$, by a two-step procedure. First, $R d$ was estimated as the rate of $\mathrm{CO}_{2}$ evolution at $\mathrm{Ci}=\Gamma^{*}$. Then, $V_{\mathrm{c} \text { max }}$ was obtained from the $\mathrm{A} / \mathrm{Ci}$ curves by nonlinear regression techniques using equation [1].

\section{Light response curves}

The light response curve of photosynthesis was obtained at $25 \mathrm{~Pa}$ of $\mathrm{CO}_{2}\left(C_{2}\right)$, and $2 \mathrm{kPa}$ of $\mathrm{O}_{2}$ by decreasing incident light intensity (I) from 1500 to $0 \mu \mathrm{mol} \mathrm{m} \mathrm{m}^{-2} \mathrm{~s}^{-1}$. At low light $(<200 \mu \mathrm{mol}$ $\left.\mathrm{m}^{-2} \mathrm{~s}^{-1}\right)$, RubP regeneration becomes limiting and $\mathrm{CO}_{2}$ assimilation is given by:

$$
A=\frac{J\left(C i-\Gamma^{*}\right)}{4.5\left(C i+7 / 3 \Gamma^{*}\right)}-R d
$$

Where $J$ is the rate of electron transport and is the smaller root of the following equation:

$$
\theta \mathcal{F}^{2}-\left(J_{\max }+\alpha l\right) J+\alpha / J_{\max }=0
$$

$\theta$ is the convexity of the quantum response of the potential electron transport of needles and was fixed at 0.79 (Leverenz and Jarvis, 1979). $\alpha$ is the initial slope of the quantum response curve of potential electron transport, $J_{\max }$ is the maximal rate of electron transport. We used a constant value of $\Gamma^{\star}(2.5 \mathrm{~Pa})$ to calculate $J_{\max }$ and $\alpha$. This value does not differ from those obtained in other $\mathrm{C}_{3}$ species (Farquhar et al,1980; Brooks and Farquhar, 1985; Wang and Jarvis, 1993). Nonlinear least squares regression techniques were used to determine best values of both $J_{\max }$ and $\alpha$ from the A/PAR curves using equations [2] and [3].

\section{Measurements of $P, N$, leaf nonstructural carbohydrate content and pigment foliar concentrations}

Measurements of foliar starch and soluble sugar concentrations were made on the ten needles used for gas exchange measurements. The day after the measurement of gas exchanges, five needles were harvested at the beginning of the photoperiod when the other five needles were harvested at the end of the photoperiod. Needles were weighed and immediately frozen at $-20^{\circ} \mathrm{C}$, then lyophilized. Starch content was determined as described by Kunst et al (1984). Soluble sugars were extracted with hot ethanol-water buffer $(80-20 \mathrm{v} / \mathrm{v})$ and measured by high performance liquid chromatography after purification on ion exchange resin (Moing and Gaudillère, 1992). Five other dried needles were digested in sulphuric acid and $\mathrm{N}$ and $\mathrm{P}$ foliar content were determined using a Technicon auto-analyser II as described in O'Neill and Webb (1970). Chlorophyll levels were determined in $\mathrm{N}$-dimethylformamide $80 \%$ according to Inskeep and Bloom (1985). 


\section{Biomass and data analysis}

Following measurements of gas exchange, seedlings were harvested and shoot and root dry weights were determined after drying for 2 days at $60^{\circ} \mathrm{C}$. Biomass analysis was made on 20 seedlings per treatment. Statistical analysis including analysis of variance and Student-Newman-Keuls test were performed using the SAS software package (SAS Institute Inc, Cary, NC, USA).

\section{RESULTS}

The total biomass of 1-year-old seedlings grown under 0.125 (P1) and $0.5 \mathrm{mM}$ (P4) phosphorus supply was about 80 and $100 \mathrm{~g}$ per plant, respectively. In contrast, seedlings supplied with no supplemental $P$ averaged $23 \mathrm{~g}$ dry weight. The shoot dry weight was three- and four-fold greater in $\mathrm{P} 1$ and $\mathrm{P} 4$ treatments, respectively, than in the P-deficient treatment (fig 1). The root dry weight was less affected by phosphorus deficiency than shoot dry weight. However, it was also two- and three-fold greater in P1 and P4 treatments, respectively, than in the P-deficient treatment (fig 1). A significant difference was observed in both shoot and root dry weight between $\mathrm{P} 1$ and $\mathrm{P} 4$ treatments. The root/shoot ratio was about $0.42 \pm 0.06$ in the P-deficient treatment as compared with $0.30 \pm 0.06$, and $0.32 \pm 0.04$ in the $\mathrm{P} 1$ and $\mathrm{P} 4$ treatments, respectively. Specific leaf area was about 91 g.m $\mathrm{m}^{-2}$ and was not affected by phosphorus nutrition.

Phosphorus deficiency did not affect the foliar nitrogen concentration. As expected, the foliar levels of phosphorus decreased from 0.15 and $0.17 \%$ dry weight in adequate phosphorus nutrition (P1 and P4 treatments, respectively) to $0.07 \%$ in $P$ deficient plants (fig 2).

Figures 3 and 4 illustrate response curves of photosynthesis to leaf internal partial pressure of $\mathrm{CO}_{2}\left(c_{1}\right)$ and to light, respectively. Phosphorus deficiency decreased the maximal rate of photosynthesis and the carboxylation efficiency (table I) by 40 and
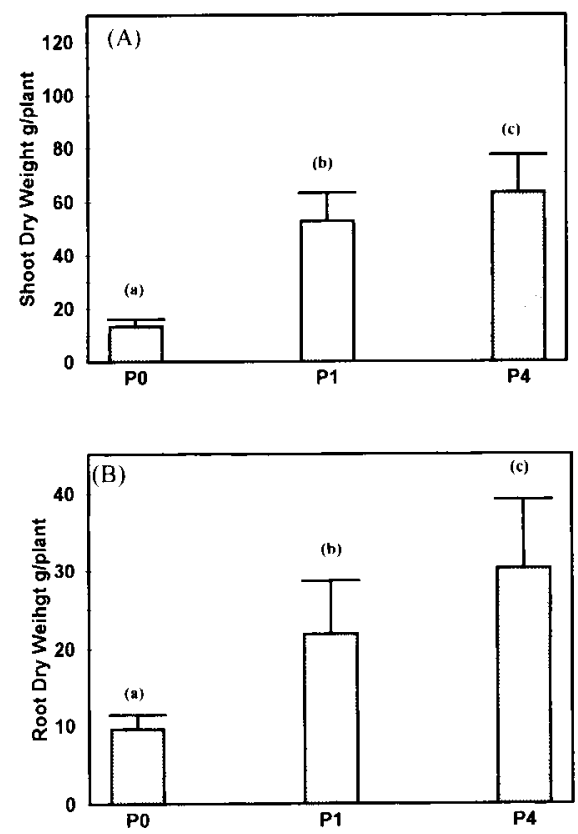

Fig 1. Dry weight of shoots $(\mathbf{A})$ and roots $(B)$ of seedlings of maritime pine associated with three phosphorus levels ( $\mathrm{P} 0=0, \mathrm{P} 1=0.125$ and $\mathrm{P} 4=0.5 \mathrm{mM}$ ). Values are the means of 20 seedlings. Error bars give the standard deviation. Values annotated with the same letter are not significantly different at $P=0.05$ (Student-Newman test after Anova).

$42 \%$, respectively. No significant difference was found for $J_{\max }$ but phosphorus deficiency significantly affected $\alpha$, which decreased by $25 \%$ in the P-deficient plants (table I).

Figure 5 shows the response curves of stomatal conductance to light in seedlings treated with three levels of phosphorus. Stomatal conductance was quite variable between seedlings in each treatment. As a consequence, there were no significant differences associated with $P$ treatment. Total chlorophyll was increased with phosphorus deficiency (table II).

Foliar starch levels were similar at the beginning of the photoperiod in the three 

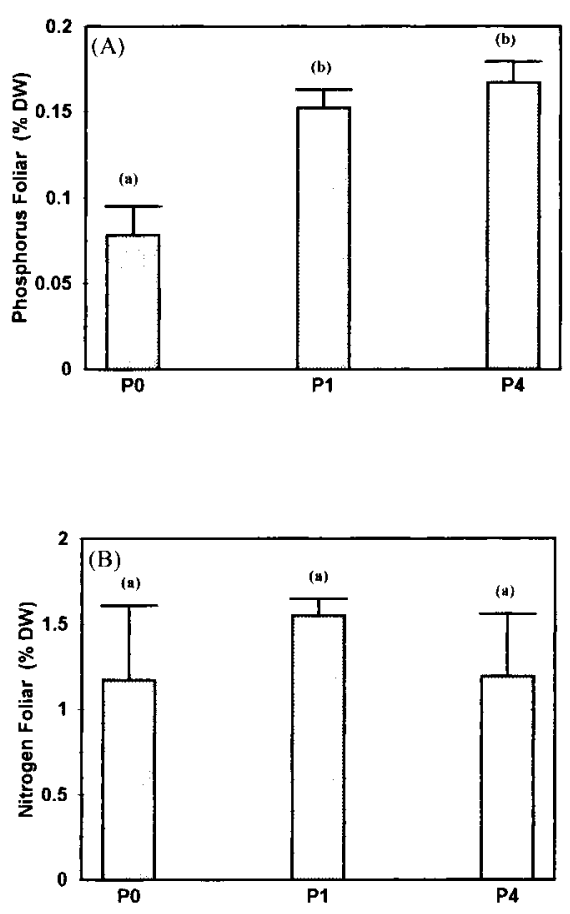

Fig 2. Phosphorus (A) and nitrogen (B) foliar concentrations in 1-year-old needles associated with three phosphorus levels $(P 0=0$, $\mathrm{P} 1=0.125$ and $\mathrm{P} 4=0.5 \mathrm{mM}$ ). Values are the means of three seedlings. Error bars give the standard deviation. Values annotated with the same letter are not significantly different at $P=0.05$ (Student-Newman test after Anova).

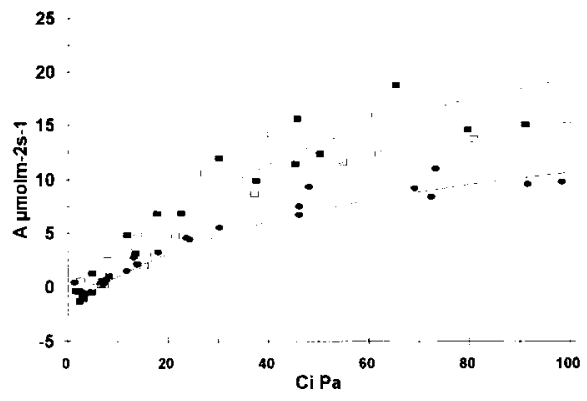

Fig 3. Photosynthesis (A) versus Cicurves obtained for nine plants at $22{ }^{\circ} \mathrm{C}, 1500 \mu \mathrm{mol} \mathrm{m} \mathrm{m}^{-2}$ $\mathrm{s}^{-1} \mathrm{PAR}, 75 \% \mathrm{RH}$ and $20 \mathrm{kPa}$ of $\mathrm{O}_{2}$. Symbols are data ([ ]P0; [ ]P1; [ ]P4), and curves ([-]PO; [----] P1; [ - - ] P4) show the fitted model using the mean values of each photosynthetic parameter for any treatment. $\mathrm{P} 0, \mathrm{P} 1$ and $\mathrm{P} 4$ refer to the three phosphorus levels $(0,0.125$ and $0.5 \mathrm{mM})$.

treatments, and increased in P-deficient treatment by $192 \%$ at the end of the photoperiod (fig 6). Glucose was two-fold greater in P-deficient treatment, and no significant differences were found for sucrose and fructose at the end of the photoperiod (table II).

\section{DISCUSSION}

Phosphorus deficiency decreased dramatically the total dry weight per plant, and affected the shoots' more than the roots' dry weight. This caused an increase in the

Table I. Mean values $(n=3)$ of maximum rate of photosynthesis $\left(A_{\max }\right)$, light saturated rate of electron transport $\left(J_{\max }\right)$, quantum efficency $(\alpha)$ and maximal velocity of carboxylation ( $\left.V_{c} \max \right)$ according to the phosphorus concentration in the nutrient solution.

\begin{tabular}{|c|c|c|c|}
\hline \multirow[b]{2}{*}{ Variable } & \multicolumn{3}{|c|}{ Treatment } \\
\hline & $\begin{array}{c}P O \\
(O \mathrm{mM})\end{array}$ & $\begin{array}{c}P 1 \\
(0.125 \mathrm{mM})\end{array}$ & $\begin{array}{c}P 4 \\
(0.5 \mathrm{mM})\end{array}$ \\
\hline$A_{\max }\left(\mu \mathrm{mol} \mathrm{m^{2 }} \mathrm{s}^{-1}\right)$ & $12.21 \pm 1.28^{a}$ & $19.05 \pm 1.77^{b}$ & $21.42 \pm 3.82^{b}$ \\
\hline$J_{\max }\left(\mu \mathrm{mol} \mathrm{m}^{2} \mathrm{~s}^{-1}\right)$ & $41.33 \pm 3.68^{a}$ & $54.50 \pm 12.5^{\mathrm{a}}$ & $64.33 \pm 14.0^{a}$ \\
\hline$\alpha$ (mol $\mathrm{CO}_{2} / \mathrm{mol}$ photon) & $0.21 \pm 0.03^{a}$ & $0.27 \pm 0.04^{b}$ & $0.31 \pm 0.11^{b}$ \\
\hline$V_{c \max }\left(\mu \mathrm{mol} \mathrm{m} \mathrm{m}^{2} \mathrm{~s}^{-1}\right)$ & $19.47 \pm 1.99^{\mathrm{a}}$ & $28.40 \pm 8.07^{\mathrm{ab}}$ & $34.09 \pm 2.92^{b}$ \\
\hline
\end{tabular}

In the same line, values annoted by the same letter are not significantly different $(P=0.05)$ (Student-Newman test after Anova). 


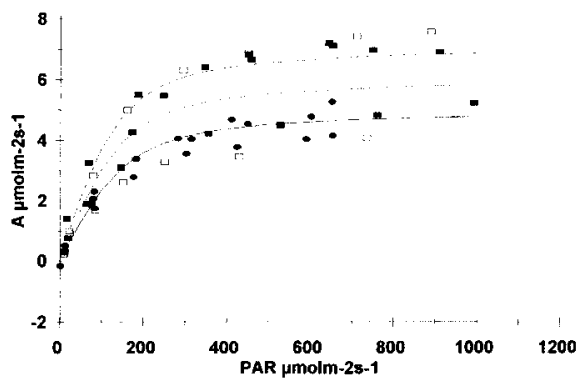

Fig 4. Photosynthesis (A) versus $P A R$ curves obtained for nine plants at $22{ }^{\circ} \mathrm{C}, 75 \% \mathrm{RH}, 25$ $\mathrm{Pa}$ of ambient $\mathrm{CO}_{2}$ and $2 \mathrm{kPa}$ of $\mathrm{O}_{2}$. Symbols are data ([ ]P0; [ ] P1; [ ] P4), and curves ([-] P0; $[---] P 1 ;[---] P 4)$ show the fitted model using the mean values of each photosynthetic parameter for any treatment. $\mathrm{P} 0, \mathrm{P} 1$ and $\mathrm{P} 4$ refer to the three phosphorus levels $(0,0.125$ and 0.5 $\mathrm{mM}$ ).

root/shoot ratio. This effect of phosphorus deficiency on root/shoot ratio has also been observed in different species and under different growth conditions (Ericsson and Ingestad, 1988; Rao and Terry, 1989; Kirschbaum et al, 1992; Topa and Cheeseman, 1992). Changes in root/shoot ratio may have resulted from the stronger sink competition of the roots for phosphorus and photosynthate when the supply of a mineral nutrient was limited. In our experiment, total biomass was significantly greater in the $\mathrm{P} 4$ versus the $\mathrm{P} 1$ treatment even if photosynthesis did not seem to differ be-

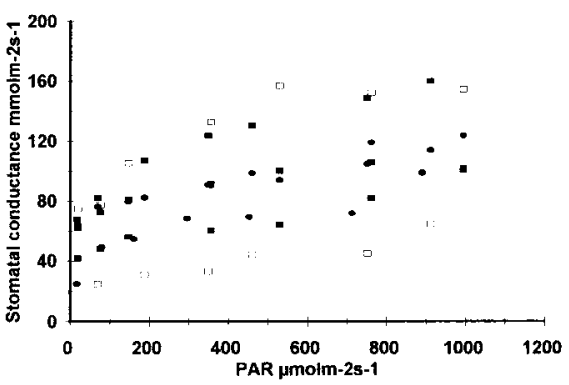

Fig 5. Response curve of stomatal conductance to light intensity for three seedlings of each treatment ([ ]P0; [ ]P1; [ ]P4). Measurements were made at $22{ }^{\circ} \mathrm{C}, 75 \% \mathrm{RH}, 25 \mathrm{~Pa}$ of ambient $\mathrm{CO}_{2}$, and $2 \mathrm{kPa}$ of $\mathrm{O}_{2}$. $\mathrm{P} 0, \mathrm{P} 1$ and $\mathrm{P} 4$ refer to the three phosphorus levels $(0,0.125$ and $0.5 \mathrm{mM})$.

tween these treatments. Phosphorus nutrition could have presumably affected growth more than photosynthesis rate.

Phosphorus concentration values found in the needles cover the range observed in different experimentations on pine species where phosphorus supply was controlled and effects on growth and photosynthesis were observed. In Pinus radiata seedlings, phosphorus deficiency decreased leaf $P$ concentration from 0.13 to $0.07 \%$ dry weight and total dry matter by $35 \%$, but the light saturated photosynthesis rate under ambient $\mathrm{CO}_{2}$ was unaffected (Conroy et al, 1990). Conversely, in Pinus taeda seedlings, Rousseau and Reid (1990) found that the dry matter and the net photosynthesis

Table II. Mean values $(n=3)$ of glucidic foliar concentration (sucrose, glucose and fructose) and chlorophyll content according to the phosphorus concentration in the nutrient solution.

\begin{tabular}{|c|c|c|c|}
\hline \multirow[b]{2}{*}{ Variable } & \multicolumn{3}{|c|}{ Treatment } \\
\hline & $\begin{array}{c}P O \\
(O \mathrm{mM})\end{array}$ & $\begin{array}{c}P 1 \\
(0.125 \mathrm{mM})\end{array}$ & $\begin{array}{c}P 4 \\
(0.5 \mathrm{mM})\end{array}$ \\
\hline Foliar sucrose (\% DW) & $0.39 \pm 0.16^{\mathrm{a}}$ & $0.38 \pm 0.14^{a}$ & $0.27 \pm 0.10^{\mathrm{a}}$ \\
\hline Foliar glucose (\% DW) & $0.43 \pm 0.07^{a}$ & $0.20 \pm 0.04^{b}$ & $0.19 \pm 0.06^{b}$ \\
\hline Foliar fructose (\% DW) & $0.27 \pm 0.02^{a}$ & $0.21 \pm 0.05^{a}$ & $0.20 \pm 0.07^{a}$ \\
\hline Chlorophyll ( $\mu \mathrm{g} / \mathrm{g} \mathrm{FW})^{\prime}$ & $1235 \pm 35^{\mathrm{a}}$ & $866 \pm 55^{b}$ & $1047 \pm 80^{c}$ \\
\hline
\end{tabular}

In the same line, values annoted by the same letter are not significantly different $(\alpha=0.05)$ (Student-Newman test after Anova). 
rate (measured at $500 \mu \mathrm{mol} \mathrm{m} \mathrm{m}^{-2} \mathrm{~s}^{-1}$ of PAR and ambient $\mathrm{CO}_{2}$ ) increase similarly when leaf $P$ concentration increase from 0.05 to $0.1 \%$ dry weight. In mycorrhizal seedlings of Pinus resinosa, phosphorus fertilization increased the shoot phosphorus concentration from 0.09 to $0.16 \%$; total dry matter increased with increasing phosphorus supply but no data have been reported on photosynthesis (Macfall et al, 1992). Lewis et al (1994) observed a reduction in triose$P$ utilization and maximal carboxylation efficiency in nonmycorrhizal seedlings grown with limiting phosphorus, the leaf $P$ concentration of which being 0.076 versus 0.12 $0.15 \%$ in other treatments.

Specific leaf area was not affected by phosphorus nutrition; thus our results on gas exchange measurements were not changed when expressed on either a dry weight or a leaf area basis. However, Kirschbaum et al (1992) found that the specific leaf area increased with increasing phosphorus supply in 6-month-old seedlings of Eucalyptus grandis and then, plateaued at higher leaf phosphorus concentrations.

In our study, the maximal rate of photosynthesis $\left(A_{\text {max }}\right)$ was $42 \%$ less in P0 treated seedlings than in either $\mathrm{P} 1$ or $\mathrm{P} 4$ (table I). Such a decrease in photosynthesis rate in phosphorus-deficient plants have been related to different causes: a smaller amount and/or specific activity of Rubisco (Lauer et al, 1989), a decreased rate of RubP regeneration (Rao and Terry, 1989) or a slower transport of triose $P$ out of chloroplast (Jacob and Lawlor, 1993). In the latter cases, the response curve of photosynthesis to leaf internal partial pressure of $\mathrm{CO}_{2}(c)$ showed either a plateau (Harley et al, 1992) or even a decreased rate with high c (Lewis et al, 1994). In our experiment, photosynthesis increased progressively and did not attain a plateau when $c$, was above $60 \mathrm{~Pa}$ (fig 3). In addition, phosphorus deficiency did not affect the maximal rate of electron transport (table I). Moreover, the carboxylation effi-
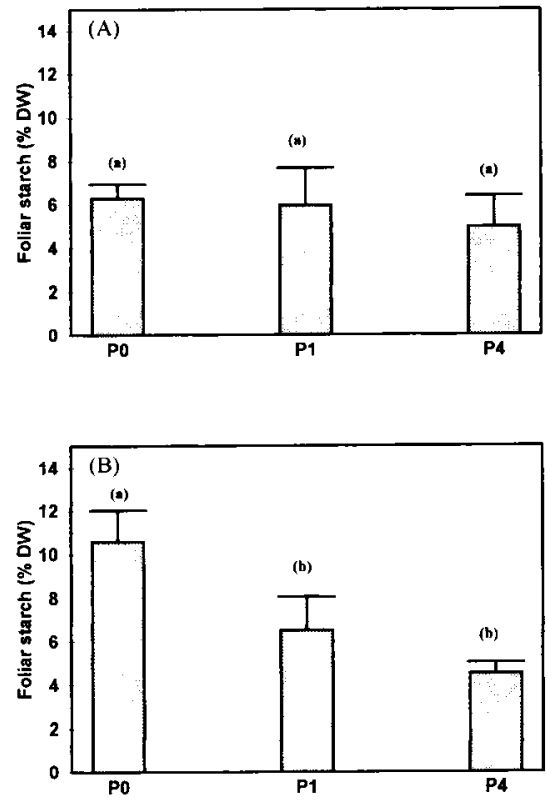

Fig 6. Starch content (\% dry weight) of the needles at the beginning $(A)$ and the end $(B)$ of the photoperiod according to the phosphorus concentration in the nutrient solution. Values are the means for three seedlings. Error bars give the standard deviation. Values annotated with the same letter are not significantly different at $P=0.05$ (Student-Newman test after Anova).

ciency was decreased in P-deficient plants (table 1). These results suggest that photosynthesis was limited rather by the Rubisco activity in $\mathrm{P}$-deficient seedlings than by triose $P$ or RubP regeneration. Alternatively, we are aware that a reduction in mesophyll conductance could also contribute to this reduction in the apparent carboxylation efficiency. We did not estimate the mesophyll conductance to $\mathrm{CO}_{2}$ diffusion, but such a change induced by phosphorus deficiency seems doubtful and has never been observed.

The decrease of carboxylation efficiency in P-deficient plants suggests an effect of 
low $\mathrm{P}$ nutrition on the amount and/or activity of Rubisco per unit leaf area. Such an effect has been reported for spinach (Brooks, 1986), soybean (Lauer et al, 1989), and loblolly pine (Tissue et al, 1993). In our experiment, nitrogen foliar concentration was not affected by phosphorus deficiency, and if we assume the amount of Rubisco to be proportional to the leaf nitrogen concentration, then phosphorus deficiency may have affected more the activity of Rubisco than its amount per unit leaf area.

The mechanism by which phosphorus deficiency affects Rubisco activity is still unclear. Several studies showed that phosphorus deficiency results in a significant increase in the activities of some Calvin cycle enzymes while significantly decreasing others. In most $C_{3}$ species, $P$ deficiency decreased activities of PGA-kinase, NADPG3P-dehydrogenase and RubP-kinase, while activities of fructose-kinase, fructose1,6-aldolase and stromal sedoheptulose-1,7bisphosphatase were increased (Woodrow et al, 1983; Sicher and Kremer, 1988; Rao and Terry, 1989). Changes in activities of these enzymes could regulate the activity of Rubisco to obtain an equilibrium of the photosynthetic carbon reduction cycle. In addition, the decrease on Rubisco activity could be due to low stromal Pi in P-deficient seedlings (Herold, 1980; Lawlor, 1987).

Apparent quantum efficiency was decreased in phosphorus-deficient seedlings at $2 \mathrm{kPa}$ of $\mathrm{O}_{2}$. This result suggests a reduced ability of the photosynthetic system to utilize photons for $\mathrm{CO}_{2}$ assimilation and indicated that phosphorus deficiency affected the photochemical reactions of photosynthesis. This may be explained by low pool sizes of ATP in the phosphorusdeficient seedlings and/or feedback effects for electron transport chain components (Abadia et al, 1987). A decrease in total adenylates levels in $\mathrm{P}$-deficient plants has already been reported by Rao et al (1989), Fredeen et al (1990) and Jacob and Lawlor (1992, 1993).
In our experiment, the estimated maximal rate of electron transport was not affected by phosphorus deficiency (table I). This could be due to the higher level of chlorophyll in the P-deficient plant (table II). Phosphorus deficiency has also been demonstrated to increase foliar chlorophyll levels in Beta vulgaris (Abadia et al, 1987). Maximal electron transport was not affected by phosphorus deficiency in mycorrhizal seedlings of Pinus taeda (Lewis et al, 1994).

Stomatal conductance was apparently not affected by $P$ nutrition (fig 6 ). Similarly, the decreased photosynthetic capacity of leaves with inadequate phosphate was associated with changes in mesophyll factors versus changes in stomatal conductance in Helianthus annus, Zea mays and Triticum aestivum (Jacob and Lawlor, 1991). Even in Eucalyptus grandis seedlings, where a stomatal limitation induced by phosphorus deficiency was observed, phosphorus nutrition had a greater influence on photosynthetic capacity than on stomatal conductance (Kirschbaum and Tompkins, 1990).

Glucidic foliar status was also affected by phosphorus deficiency. Starch synthesis was more affected than nonstructural carbohydrates. Our results show an increase in foliar starch level in P-deficient plants (fig 5). No significant difference was observed in foliar sucrose level between the P-deficient seedlings and the P1 and P4 treatments (table I). Starch accumulation appeared to be a direct consequence of $P$ depletion in other $\mathrm{C}_{3}$ species (Waring et al, 1985; Foyer and Spencer, 1986; Sicher and Kremer, 1988; Arulanatham et al, 1990; Conroy et al, 1990). This was attributed to low stromal $\mathrm{Pi}$ concentration because cytosolic $\mathrm{Pi}$ is needed to export the triose phosphates from the stroma via the phosphate translocator. Otherwise the triose phosphate get stored in the chloroplast as starch. However, the mechanisms by which starch accumulation occur in leaves of P-deficient plants are not clearly 
established (Qiu and Israel, 1992). Two mechanisms could explain this interaction: i) a direct effect of $P$ depletion on an enzymatic step(s) of photosynthesis may reduce the export of triose phosphates from the chloroplast; ii) an indirect effect through sink activity so that triose $P$ synthesized in excess of immediate requirement by sinks activity are stored as temporary reserves into the chloroplast. If the first mechanism is operative, then starch accumulation into the chloroplast may be partially responsible for decreased growth under phosphorus deficiency. If the second mechanism is operative, then starch accumulation may be the result and not the cause of decreased growth. These two mechanisms are not antagonistic and may be operative simultaneously to regulate growth and photosynthesis in P-deficient plants.

In our experiment, the starch accumulation observed in P-deficient seedlings was probably due to either one or both of these mechanisms because the P deficiency reduced both growth and photosynthesis. However, the total dry matter of the P1 seedlings was lower than $\mathrm{P} 4$ seedlings but photosynthesis was unchanged. In addition, starch accumulation in $\mathrm{P} 1$ seedlings was increased slightly compared to the P4 treatment. Then, only the second mechanism may be operative in this case.

In conclusion, phosphorus deficiency reduced both growth and photosynthesis of 1-year-old maritime pine seedlings and it appears to affect carbon assimilation mainly through the carboxylation efficiency and the apparent quantum efficiency. In addition, starch accumulation was increased in the needles of phosphorus-deficient plants.

\section{ACKNOWLEDGMENTS}

The authors thank M Sartore and C Lambrot for their technical assistance. PhD fellowship of the senior author (GW) was supported by 'La Division de la recherche et de l'expérimentation forestière, Maroc' and 'Ministère de la Coopération,
France'. The research work was supported by the Region Aquitaine project 'Étude des écosystèmes sableux', 1994-1998.

\section{REFERENCES}

Abadia J, Rao IM, Terry N (1987) Changes in leaf phosphate status have only small effects on the photochemical apparatus of sugar beet leaves. Plant Sci 50, 49-55

Arulanatham AR, Rao M, Terry N (1990) Limiting factors in photosynthesis. Regeneration of ribulose-1,5-bisphosphate limits photosynthesis at low photochemical capacity. Plant Physiol 93, 1466-1475

Brooks A (1986) Effects of phosphorus nutrition on ribulose-1,5-bisphosphate carboxylase activation, photosynthetic quantum yield and amounts of some Calvin cycle metabolites in spinach leaves. Austr J Plant Physiol 13, 221-237

Brooks A, Farquhar GD (1985) Effect of temperature on the $\mathrm{CO}_{2} / \mathrm{O}_{2}$ specificity of ribulose-1-5-bisphosphate carboxylase/oxygenase and the rate of respiration in the light. Planta 165, 397-406

Conroy JP, Milham PJ, Bevege DI, Barlow EWR (1990) Influence of phosphorus deficiency on the growth response of four families of Pinus radiata seedlings to $\mathrm{CO}_{2}$-enriched atmospheres. For EcolManage 30 , 175-188

Cromer RN, Jarvis PG (1990) Growth and biomass partitioning in Eucalyptus grandis seedlings in response to nitrogen supply. Austr J Plant Physiol 17, 503-515

Ericsson T, Ingestad T (1988) Nutrition and growth of birch seedlings at varied relative phosphorus addition rates. Physiol Plant 72, 227-235

Farquhar GD, Von Cammerer S, Berry JA (1980) A biochemical model of photosynthetic $\mathrm{CO}_{2}$ assimilation in leaves of $\mathrm{C}_{3}$ species. Planta 149, 78-90

Foyer C, Spencer C (1986) The relationship between phosphate status and photosynthesis in leaves. Effects on intracellular orthophosphate distribution, photosynthesis and assimilate partitioning. Planta 167, 369-375

Fredeen AL, Raab TK, Rao IM, Terry N (1990) Effects of phosphorus nutrition on photosynthesis in Glycine max L Merr. Planta 181, 399-405

Gelpe J, Guinaudeau J (1974) Essai de fertilisation sur pins maritimes à Mimizan (Landes). Résultats après la seizième année. Rev For Fr 26, 459-463

Gelpe J, Lefrou G (1986) Essai de fertilisation sur pins maritimes à Mimizan (Landes). Résultats après la $26^{\mathrm{e}}$ année. Rev For Fr 38, 394-400

Harley PC, Thomas RB, Reynolds JF, Strain BR (1992) Modelling photosynthesis of cotton grown in elevated $\mathrm{CO}_{2}$. Plant Cell Environ 15, 271-282

Herold A (1980) Regulation of photosynthesis by sink activity - the missing link. New Phytol 86, 131-144

Inskeep WP, Bloom PR (1985) Extraction coefficients chlorophyll $\mathrm{a}$ and $\mathrm{b}$ in $\mathrm{N}$-dimethylformamide and $80 \%$ acetone. Plant Physiol 77, 483-485

Jacob J, Lawlor DW (1991) Stomatal and mesophyll limitations of photosynthesis in phosphate deficient 
sunflower, maize, and wheat plants. J Exp Bot 42, 1003-1011

Jacob J, Lawlor DW (1992) Dependence of photosynthesis of sunflower and maize leaves on phosphate supply, ribulose-1,5-bisphosphate carboxylase/oxygenase activity and ribulose-1,5-bisphosphate pool size. Plant Physiol 98, 801-807

Jacob J, Lawlor DW (1993) in vivo photosynthetic electron transport does not limit photosynthetic capacity in phosphate-deficient sunflower and maize leaves. Plant Cell Environ 16, 785-795

Kirschbaum MUF, Tompkins D (1990) Photosynthetic responses to phosphorus nutrition in Eucalyptus grandis seedlings. Austr J Plant Physiol 17, 527-535

Kirschbaum MUF, Bellingham DW, Cromer RN (1992) Growth analysis of effect of phosphorus nutrition on seedlings of Eucalyptus grandis. Austr J Plant Physiol 19, 55-66

Kunst A, Draeger B, Ziegenhorn J (1984) Carbohydrates, UV method with hexokinase and glucose-6phosphate dehydrogenase. In: Enzymatic Analysis (Bergmeyer, ed), Verlag, Basel, 163-172

Lauer MJ, Pallardy SG, Blevins DG, Randall DD (1989) Whole leaf carbon exchange characteristics of phosphate deficient soybeans (Glycine max L). Plant Physiol 91, 874-854

Lawlor DW (1987) Photosynthesis, Molecular, Physiological, and Environmental Processes. Longman Scientific and Technical, New York

Leuning R (1990) Modelling stomatal behaviour and photosynthesis of Eucalyptus grandis. Austr J Plant Physiol 17, 159-175

Leverenz JW, Jarvis PG (1979) Photosynthesis in Sitka spruce. VIII. The effects of light flux density and direction on the rate of net photosynthesis and the stomatal conductance of needles. $J$ Appl Ecol 16, 919-932

Lewis JD, Griffen KL, Thomas RB, Strain BR (1994) Phosphorus supply affects the photosynthetic capacity of loblolly pine grown in elevated carbon dioxide. Tree Physiol 14, 1229-1244

MacFall JS, Slack SA, Wehrli S (1992) Phosphorus distribution in red pine roots and the ectomycorrhizal fungus Hebeloma arenosa. Plant Physiol 100, 713-717

Moing A, Gaudillère JP (1992) Carbon and nitrogen partitioning in peach/plum grafts. Tree Physiol 10, 81-92

Marschner H(1991) Plant-soil relationships: acquisition of mineral nutrients by roots from soils. In: Plant Growth Interactions with Nutrition and Environment (Porter and Lawlor, eds), Society for Experimental Biology, Cambridge, UK, 125-156

O'Neill JV, Webb RA (1970) Simultaneous determination of nitrogen, phosphorus, and potassium in plant material by automatic methods. J Sci Food Agric 21, 217-219
Qiu J, Israel W (1992) Diurnal starch accumulation and utilisation in phosphorus-deficient soybean plants. Plant Physiol 98, 316-323

Rao IM, Terry N (1989) Leaf phosphate status, photosynthesis, and carbon partitioning in sugar beet. I. Changes in growth, gas exchange, and Calvin cycle enzymes. Plant Physiol 90, 814-819

Rao IM, Arulanatham AR, Terry N (1989) Leaf phosphate status, photosynthesis, and carbon partitioning in sugar beet. II. Diurnal changes in sugar phosphates, adenylates, and nicotinamide nucleotides. Plant Physio/ 90, 820-826

Rousseau JVD, Reid CPP (1990) Effects of phosphorus and ectomycorrhizas on the carbon balance of loblolly pine seedlings. For Sci 36, 101-112

Sage FR (1990) A model describing the regulation of ribulose 1-5-bisphosphate carboxylase, electron transport, and triose phosphate use in response to light intensity and $\mathrm{CO}_{2}$ in $\mathrm{C}_{3}$ species. Plant Physiol $94,1728-1734$

Saur E (1989) Effet de l'apport de phosphore, de carbonate de calcium et d'oligoéléments ( $\mathrm{Cu}, \mathrm{Mn}, \mathrm{Zn} \mathrm{B}$ ) à trois sols sableux acides sur la croissance et la nutrition de semis de Pinus pinaster Ait. I. Croissance et nutrition en éléments majeurs. agronomie 9, 931-940

Sheriff DW, Nambiar EKS, Fife DN (1986) Relationships between nutrient status, carbon assimilation and water use efficiency in Pinus radiata needles. Tree Physiol 2, 73-88

Sicher RC, Kremer DF (1988) Effects of phosphate deficiency on assimilate partitioning in barley seedlings. Plant Sci 57, 9-17

Tissue DT, Thomas RB, Strain BR (1993) Long-term effects of elevated $\mathrm{CO}_{2}$ and nutrients on photosynthesis and Rubisco in loblolly pine seedlings. Plant Cell Environ 16, 859-865

Topa MA, Cheeseman JM (1992) Carbon and phosphorus partitioning in Pinus serotina seedlings growing under hypoxic and low-phosphorus conditions. Tree Physiol 10, 195-207

Von Caemmerer S, Farquhar GD (1981) Some relationships between the biochemistry of photosynthesis and the gas exchange of leaves. Planta 153, 376-387

Wang YP, Jarvis PG (1993) Influence of shoot structure on the photosynthesis of sitka spruce (Picea sitchensis). Funct Ecol 7, 433-451

Waring $\mathrm{RH}$, McDonald AJS, Larsson S, Ericsson T, Wiern A, Arwidsson E, Ericsson A, Lohammar T (1985) Differences in chemical composition of plants grown at constant relative growth rates with stable mineral nutrition. Oecologia 66, 157-160

Woodrow IE, Murphy DJ, Walker DA (1983) Regulation of photosynthetic carbon metabolism. The effect of inorganic phosphate on stromatal sedoheptulose1,7-bisphosphatase. Eur J Biochem 132, 121-123 